Elsewhere in the Scottish report ${ }^{1}$ Doctors in an Integrated Health Service it states that "the community medicine specialist could ensure that rehabilitation and after-care were co-ordinated." Perhaps it would have been prudent, before pre-empting areas of rehabilitation for this new grouping of community medicine, to wait until the two committees which have been studying the place of rehabilitation within the Health Service for the past three years in England and Wales and in Scotland, under the chairmanship of Sir Ronald Tunbridge and myself respectively, had reported. This should be in a few weeks' time.-I am, etc.,

Alex MAIR

Department of Social and Occupational Medicine, University of Dundee

1 Scottish Home and Health Department, Doctors in an Integrated Health Service. Edinburgh,
H.M.S.O., 1971.

\section{Epidemic Keratoconjunctivitis}

SIR,-We wish to draw attention to the fact that several outbreaks of epidemic keratoconjunctivitis are occurring in Britain at present. In Western countries the causal virus (adenovirus type 8 ) is almost entirely spread from patient to patient by medical personnel. ${ }^{1-3}$ Since the disease is sufficiently incapacitating for patients to be unable to work for up to a month and the corneal opacities may persist for very much longer, it is important to try to prevent this spread. We suggest that while reviewing aseptic techniques, the following precautions might be considered in ophthalmic clinics.

(1) The immediate suspension from work of all doctors and nurses who acquire the infection.

(2) If an outbreak occurs, the segregation of patients with keratoconjunctivitis to a special clinic, perhaps on Saturday mornings.

(3) The placing of disposable rubber sheaths on tonometers when examining such patients.

(4) The wearing of a disposable glove when manipulating the eyelids of patients with keratoconjunctivitis.-We are, etc.,

J. C. DeAn Hart

Bristol Eye Hospital

V. J. MARMION

Bristol Public Health Laborator

S. K. R. Clarke

Bristol Royal Infirmary

D. L. BARNARD

1 Thygeson, P., American fourn bridge, 1958, 56, 101 .

Dawson, C., and Darrell, R. New England fournal of Medicine, 1963, 268, 1031.

\section{A Kidney from the Family}

SIR,-We read with interest your leading article "A Kidney from the Family" (24 July, p. 202), written in response to our article "Family Tension in the Search for a Kidney Donor."

We do not believe that use of related kidney donors should be discouraged because of our findings. Granted, significant tension occurs as families make donor decisions. By learning about these tensions it may be possible to help ease some of them. However, the benefits of a living related donation cannot be ignored, nor can the family ten- sions associated with cadaver donation be overlooked. Presently in our centre there is at least three times the chance of dying after receiving a cadaver kidney than after receiving a related kidney, and twice the chance of rejecting the kidney. The despair and family stress after a cadaver kidney is rejected is probably much greater than the temporary stress attached to the donor decision-making process. Many family donor are quite eager to donate and our further research indicated that even when family stress occurs before the operation, it is likely to be resolved after a successful transplant.

It is our opinion that a physician must alert a volunteer related donor not only to the risks and discomforts of donation, but also to the real benefits for the patient. The fact that it is unusual for a patient's family to volunteer an organ in the United King dom might well be due to the fact that the family does not understand these benefits.

We feel it would be tragic if our finding were used to discourage related donation rather than as a guide to the use of psychological and social support for the family. We are, etc.

ROBERTA G. SIMMONS KATHLEEN HICKEY CaRL M. KJELlSTRAND RICHARD L. SIMMONS

\section{Department of Surgery,}

Minneapolis, Minnesota, U.S. A.

I Simmons, R. G., Hickey, K., Kjellstrand, C. M. and Simmons, R. L., Fournal of the American Medical Association, 1971, 215, 909.

\section{Addiction or Dependence?}

SIR,-We welcome the challenge issued by Dr. H. A. Wendel (25 September, p. 766) to our use of the word dependence (10 July, p. 70). The article was written in the hope that it would provoke re-examination of terminology and of concepts.

Dr. Wendel states correctly that in 1969 the W.H.O. Expert Committee ${ }^{1}$ wrote that drug dependence included "compulsion to take the drug." He did not mention the frequent changes in W.H.O. definitions in the last few years. Addiction used to be, and is, a perfectly good word. When bodies like the W.H.O. were obliged to consider the evidence that amphetamine addicts existed, they found themselves embarrassed by their former definitions of addiction. This rigidity led the W.H.O. to turn to dependence, but this, unlike addiction, was an ordinary word from everyday English. We are dependent on the electricity supply. We become aware of our dependence when we experience withdrawal symptoms-as in a strike by power workers. It does not mean we would be prepared to forge prescriptions, or abuse electricity through self-administered shocks.

It was part of our purpose to demonstrate that drug dependence (as dependence on the power supply) can develop unwittingly. We used, for contrast, the word abuse (though misuse looks like being a new legal term). Doctors make patients dependent on many drugs, but do not make patients abuse drugs. We stressed that fenfluramine is not a drug of abuse.

It is to be hoped that a consistent terminology, capable of withstanding advances in knowledge, will soon be adopted by W.H.O. and other bodies. Addiction could well return; indeed it has survived. The term abuse is also needed-we know of no one who has yet published evidence that L.S.D. is a drug of addiction though it is certainly a drug of abuse. Dependence, we suggest, means just what it always has meant-that if we have gradually become dependent on someone or something, moral failings are not implied, but when withdrawal occurs we realise how we failed to appreciate what we now are missing, and sometimes we even feel depressed.-We are, etc.

IAN OSWALD

Department of Psychiatry, University cf Edinburgh,

Expert Committee on Drug Dependence, 16th Report, Series, 1969 , No $407, \mathrm{p} .6$.

\section{Anaesthesia for Cardioversion}

SIR,-Professor K. Somers and others in their article on intravenous diazepam for direct-current cardioversion (2 October, $p$ 13) make several statements and suggestions which are at variance with our experience. They state first that "no significant change of blood pressure was noticed in any patient." The present authors (unpublished work) have anaesthetized patients for major cardiac surgery with an intra-arterial needle in position, with a variety of induction agents. All were premedicated with pentobarbitone, morphine, and hyoscine. The mean arterial blood pressure in patients given diazepam slowly $(0.35 \mathrm{mg} / \mathrm{kg}$; range $12-30 \mathrm{mg}$ ), fell from $95 \mathrm{~mm} \mathrm{Hg}$ to $80 \mathrm{~mm}$ $\mathrm{Hg}$. This fall was very similar to that seen with thiopentone or methohexitone, though the minimum level was not reached for six minutes with diazepam against three minutes with the barbiturates

The view that the risk of hypoxaemia is a theoretical one is not borne out by our measurements. The arterial $\mathrm{PO}_{2}$ breathing air fell from a mean of $85 \mathrm{~mm} \mathrm{Hg}$ to 66 $\mathrm{mm} \mathrm{Hg}$ over the first three minutes. The premedication used may have played a part in both initial and final readings but again it should be said that the fall was very similar with the barbiturates. With all induction agents it was reversed by inhalation of oxygen during induction.

Using diazepam for induction of surgical anaesthesia full consciousness does not usually return until the next day, and we have seen amnesia of about 36 hours in two out of 50 cases. The short-acting intravenous agents, methohexitone and propanidid, have probably no advantages regarding hypotension but they would certainly be safer as regards ability to return home. There can be little doubt that the arterial oxygen tension falls during induction of anaesthesia with any agent and the period of cardiac instability following cardioversion would seem to be another good reason for allowing all patients to breathe oxygen during the whole period.-We are, etc.,

S. M. LYONS R. S. J. Clarke

Departments of Anaesthetics and Cardiac Surgery, Roval Victoria Hospital, Belfast

\section{Therapy-linked Leukaemia}

SIR,-We were interested in the letter by Drs. F. P. Li and D. G. Nathan (25 September, p. 765) recording the development 